\title{
Organ Specific Killing af a Dispensable Organ or a Cell Population in an Organ- A Successful Design for Cancer Therapy-A Hypothesis
}

\author{
Håkan Olsson ${ }^{1,2}$ \\ ${ }^{1}$ Department of Oncology, University Hospital, Lund, Sweden \\ ${ }^{2}$ Department of Cancer Epidemiology, Lund University, Lund, Sweden
}

*Corresponding author: Dr. Håkan Olsson, Department of Oncology, University Hospital, Lund, Sweden, Tel: ; E-mail: hakan.olsson@med.lu.se

Recieved date: May 09, 2014, Accepted date: Jun 28, 2014, Published date: Jun 30, 2014

Copyright: (c) 2014 Olasson. This is an open-access article distributed under the terms of the Creative Commons Attribution License, which permits unrestricted use, distribution, and reproduction in any medium, provided the original author and source are credited.

\begin{abstract}
Purpose: This article hypothesizes that designing cancer therapies based on the organ specific toxicity of the normal tissue of the organ from which the tumors originated could be worthwhile. A prerequisite for successful therapy is that the individual can recover from damage done to the organ or cells.
\end{abstract}

Results: Therapeutic examples are given for lymphoma, kidney cancer, melanoma and leukemia.

Conclusion: Efforts should be made to identify new agents with organ specific toxicity and study their potential as a cancer therapy for the same organ.

Keywords: Cancer therapy; Cancer; Target therapy; Melanoma

\section{Introduction}

Successful cancer therapy has been built on certain dogmas, including that both radiation and cytostatic therapy exert their main effects on dividing cells and that tumor cells have a deficient repair mechanism compared with normal cells. Therefore, fractionating the therapy is a successful way to increase the therapeutic ratio between neoplastic and normal tissue. However, maximizing the therapeutic effects on dividing cells is limited by the generalized side effects on rapidly dividing normal tissue, such as blood cells and the epithelium of the gastrointestinal tract [1].

\section{Hypothesis}

An alternative approach to treating cancer would be to target the therapy to a specific organ or its subpopulation of cells, thus avoiding generalized side effects of the therapy. Such an approach would depend on the hypothesis presented in this article supported by recent research.

The hypothesis states that there is a relationship between therapies that have organ specific toxicity and the therapeutic susceptibility of a cancer that originates from the same organ. When the organ function is dispensable or it is possible to substitute its function, the therapy is successful.

Further support for the relationship between the tumor and the organ of origin is data that suggests that tumor biology at least partly reflects the biology of the tissue/epithelial cell of origin at the time of initiation [2-4].

Examples supporting the hypothesis as described in table 1 and 2

The following research supports the suggested strategy. Antibodies directed towards B-cells carrying the CD20 antigen are very efficient in the treatment of patients with lymphoma carrying the CD20 antigen
[5] because the possible cellular origin is from the normal CD20 lymphocyte subpopulation. For the patient, it is tolerable to target both the normal and neoplastic CD20-expressing cells. Studies targeting CD22 and CD30 in patients with lymphoma with a possible similar therapeutic benefit are underway [6,7].

In a similar manner, it is possible to target HER2/neu positive breast cancer with the antibody Herceptin without severely compromising the patient [8] as the normal HER2/neu positive epithelial cells were functional in the breast at a younger age.

The toxin orellanine from the mushroom Cortinarius orellanus and Cortinarius speciocissimus is known to cause irreversible kidney failure but does not severely damage other organs, offering a possible new approach to treat metastatic kidney cancer [9]. Preliminary data suggest that orellanine would be effective in killing kidney cancer originating from the tubular cells, the same cell type that experiences the toxic effect from the fungus. After therapy, the patient would need dialysis or kidney transplantation.

To consider transplantation, the prognosis of the patient must be taken into account and the patient must have a good functional status.

An unexplored therapeutic potential would be to target therapy against melanoma by targeting the melanocyte and the melanin pathway. This could be accomplished by using an intermediary atoxisk metabolite of DOPA, 2,4-dihydroxyfenylalanin (DHPA). DHPA can be converted by tyrosinase to the highly toxic substance 6-OH-Dopa and it has shown great antitumour activity in two melanoma cell lines $[10,11]$ but has not yet been tested in humans. The glutathione system is upregulated to protect against the oxidative stress [12]. Experimental data would support that also using butioninsulfoxim, $\mathrm{BSO}$, against glutathione synthetase could be beneficial. It has been shown that the glutathione system in human melanoma cells decrease by $99 \%$ by adding BSO [13].

That a targeted activity against the melanocyte could be a fruitful approach in melanoma therapy is supported by the clinical finding 
that patients having vitiligo have a lower risk of melanoma [14]. Patients with vitiligo suffer from an autoimmune reaction against melanocytes.

In testicular cancer, the remnants of embryonic cells may be the origin of malignant teratomas that can be differentiated and cured by Platinol therapy without injuring more developed organs in the individual [1].

Tumor-involved lymph nodes can be eradicated by radiotherapy in Hodgkin's disease without compromising the immediate health of the patient. The target and doses are adapted to mainly kill the lymphocytic tissue [1].

The hypothesis is also indirectly supported by recent results of melanoma immunotherapy using antibodies against CTLA4 and the PD1 antigen, which modulate $\mathrm{T}$ cell function and thus enhance the antibody response against the tumor while inducing a generalized autoimmune response [15]. If the autoimmune reaction is tolerable for the patient, the therapy is successful.

In a similar manner, allogenic bone marrow transplantation of leukemia has a higher chance of success if the patient experiences a tolerable graft versus host reaction [1].

As an alternative approach, preventing hereditary cancer via prophylactic operations on target organs, such as the breast, ovary, colon and thyroid, represent examples where the removal of the cell of origin prevents cancer initiation. These procedures were not well understood at first, and there was criticism regarding prophylactic operations before the procedure was shown to be effective in humans $[16,17]$.

\begin{tabular}{|c|c|c|c|}
\hline & Target & Experimental data & Clinical data \\
\hline Ab (Mabthera) & $\begin{array}{l}\text { CD20+ lymphocytes } \\
\text { Lymphoma }\end{array}$ & + & + \\
\hline $\begin{array}{l}\text { Immunotoxin (CAT- } \\
\text { 3888, CAT- 8015) } \\
\text { Antibody-drug conjugate (Brentuxi- } \\
\text { mab) }\end{array}$ & $\begin{array}{l}\text { CD22+ lymphocytes } \\
\text { (Lymphoma, leukemia) } \\
\text { CD30+ lymphocytes } \\
\text { (Hodgkin lymphoma) }\end{array}$ & $\begin{array}{l}+ \\
+\end{array}$ & $\begin{array}{l}(+) \\
(+)\end{array}$ \\
\hline $\begin{array}{l}\text { Ab (HER2/neu) } \\
\text { Toxin (orellanine) }\end{array}$ & $\begin{array}{l}\text { HER2+ tumor cells } \\
\text { Kidney cancer/tubule cells }\end{array}$ & $\begin{array}{l}+ \\
+\end{array}$ & $\begin{array}{l}+ \\
-\end{array}$ \\
\hline Radiotherapy & $\begin{array}{l}\text { lymph nodes/lymphoma } \\
\text { Hodgkin's disease }\end{array}$ & + & + \\
\hline Platinol & $\begin{array}{l}\text { Testicular cancer/ } \\
\text { Teratoma }\end{array}$ & + & + \\
\hline 6-OH DOPA & Melanoma & + & - \\
\hline $\mathrm{Ab}(\mathrm{CTLA} 4)$ & $\begin{array}{l}\text { T cell function } \\
\text { Autoimmune reaction } \\
\text { Melanoma, lung, kidney cancer }\end{array}$ & + & + \\
\hline $\mathrm{Ab}(\mathrm{PD}-1)$ & $\begin{array}{l}\text { T cell function } \\
\text { Autoimmune reaction } \\
\text { Melanoma, lung, kidney cancer }\end{array}$ & + & + \\
\hline T-cell (transplantation) & $\begin{array}{l}\text { Leukemia } \\
\text { (graft vs. host) }\end{array}$ & + & + \\
\hline
\end{tabular}

Table 1: Examples of therapies that, either through experimental or clinical data, exploit the hypothesis that by injuring the cell of origin of the tumor, the tumor could also respond to therapy. $\mathrm{Ab}=$ antibody, $+=$ positive relationship, $(+)=$ studies underway, $-=$ no studies performed yet .

\begin{tabular}{|l|l|}
\hline Therapy & Toxicity of the therapy \\
\hline Ab (Mabthera) & B-cell dysfunction, infusion-related cytokine release, hypersensitivity, cardiac arrythmias [18] \\
\hline Immunotoxin (CAT-3888,CAT-8015) & $\begin{array}{l}\text { Drug-related toxicities in 25-60\% of the 28 patients included (in decreasing frequency), grade 1-2 hypoalbuminemia, } \\
\text { edema, fever, ALT and AST elevations, headaches, and nausea [19,20] }\end{array}$ \\
\hline Antibody-drug & $\begin{array}{l}\text { Hematosuppression neutropenia, neuropathy [18] } \\
\text { conjugate (Brentuximab) }\end{array}$ \\
\hline
\end{tabular}




\begin{tabular}{|l|l|}
\hline Ab (HER2/neu & Cardiomyopathy, infusion-related cytokine release [18] \\
\hline Toxin (orellanine) & Severe injury to tubule cells in the kidney [21] \\
\hline Radiotherapy & Immune defect, infectious complications [22] \\
\hline Platinol & Renal insufficiency, hearing loss, neuropathy [18] \\
\hline 6-OH DOPA & Severe neurotoxicity [11] \\
\hline Ab (CTLA4) & Autoimmune reaction [23] \\
\hline Ab (PD-1) & Autoimmune reaction [23] \\
\hline T-cell (transplantation) & Graft vs. host [24] \\
\hline
\end{tabular}

Table 2: Main toxicities associated with the therapy. $A b=$ antibody.

\section{Focus For Future Research}

Strategies for future clinical research should include the following approaches.

In high risk patients, organs that are dispensable or have a function that can be partly reconstituted or substituted should be identified and strategies should be developed for the prophylactic removal of such organs at optimal ages among high risk patients.

In cancer patients, at diagnosis or at a metastatic stage, organs that are dispensable or have a function that partly can be reconstituted or substituted should be identified. Therapies that have organ specific toxicity should be developed, and the response of the cancer originating from such an organ to the organ specific therapy should be studied.

After therapy, efforts should be made to reconstitute the organ. This reconstitution can be done by transplantation, stem cell renewal or a functional substitution.

An unsolved problem is how to target certain exposed epithelial tissues to prevent cancer from developing. Smoking-associated epithelial mutations in the respiratory and urinary tract and UV-light induced mutagenesis of the skin are examples of tissues that would be the focus of further research. Additionally, therapeutic strategies to prevent heterozygous cells from becoming mutationally homozygous using the concept of synthetic lethality in cancer prone tissues that may harbor BRCA mutations remain challenging. Thus far, this approach has only been attempted for therapy in BRCA-associated tumors (homozygous state) [25] and not for the prevention of tumors (heterozygous state).

\section{Conclusion}

Data strongly support the idea that identifying organ specific toxins would be a helpful way to find new therapeutic agents against cancer if the loss of organ function is amendable or can be reconstituted. This approach may be easier when the tumor originates from a more differentiated cell or a progenitor cell, and not a stem cell, allowing for the reconstitution of organ function by available stem cells.

Data also support the notion that the tissue of origin contributes to the tumor characteristics [2-4] and that there may be, at least in part, a common susceptibility to a therapeutic agent.
The author has no actual or potential conflict of interest including any financial, personal or other relationships with people or organizations that could inappropriately influence this work.

\section{Funding}

This work was supported by the Swedish Cancer Society, Swedish Research Council and ERC advanced grant (ERC-2011-AdG 294576risk factors cancer).

\section{References:}

1. De Vita VT. Lawrence TS, Rosenberg SA, De Pinho RA, Weinberg R. Cancer: Principles and Practice of Oncology. 2011. 9th Edition,Wolters Kluwer, Lipincott Willians \& Wilkins,

2. Olsson H (2000) Tumour biology of a breast cancer at least partly reflects the biology of the tissue/epithelial cell of origin at the time of initiation a hypothesis. J Steroid Biochem Mol Biol 74: 345-350.

3. Olsson H (2013) Cell of origin of breast cancer-an updated hypothesis merging epidemiologicaldata with molecular biology. J Carcinogenesis and Mutagenesis 4: 1

4. Ince TA, Richardson AL, Bell GW, Saitoh M, Godar S, et al. (2007) Transformation of different human breast epithelial cell types leads to distinct tumor phenotypes. Cancer Cell 12: 160-170.

5. Boross P, Leusen JH (2012) Mechanisms of action of CD20 antibodies. Am J Cancer Res 2: 676-690.

6. $\mathrm{Tu} \mathrm{X}$, LaVallee $\mathrm{T}$, Lechleider $\mathrm{R}$ (2011) $\mathrm{CD} 22$ as a target for cancer therapy. J Exp Ther Oncol 9: 241-248.

7. Vadakara J, Pro B (2012) Targeting CD30 in anaplastic large cell lymphoma. Curr Hematol Malig Rep 7: 285-291.

8. Shepard HM, Jin P, Slamon DJ, Pirot Z, Maneval DC (2008) Herceptin. Handb Exp Pharmacol : 183-219.

9. Herrmann A, Hedman H, Rosén J, Jansson D, Haraldsson B, et al. (2012) Analysis of the mushroom nephrotoxin orellanine and its glucosides. J Nat Prod 75: 1690-1696.

10. Morrison ME, Yagi MJ, Cohen G (1985) In vitro studies of 2,4dihydroxyphenylalanine, a prodrug targeted against malignant melanoma cells. Proc Natl Acad Sci U S A 82: 2960-2964.

11. Hansson C, Rorsman H, Rosengren E, Wittbjer A (1985) Production of 6-hydroxydopa by human tyrosinase. Acta Derm Venereol 65: 154-157.

12. Han SK, Mytilineou C, Cohen G (1996) L-DOPA up-regulates glutathione and protects mesencephalic cultures against oxidative stress. J Neurochem 66: 501-510.

13. Rorsman H, Albertsson E, Edholm L-E, Hansson C, Ã-gren L, et al. (1988). Thiols in the melanocyte. Pigm.Cell Res, Suppl 1: 54-60. 
Citation: Olsson H (2014) Organ Specific Killing af a Dispensable Organ or a Cell Population in an Organ- A Successful Design for Cancer Therapy-A Hypothesis. J Carcinog Mutagen 5: 179. doi:10.4172/2157-2518.1000179

Page 4 of 4

14. Jin Y, Birlea SA, Fain PR, Ferrara TM, Ben S, et al. (2012) Genome-wide association analyses identify 13 new susceptibility loci for generalized vitiligo. Nat Genet 44: 676-680.

15. McArthur GA, Ribas A (2013) Targeting oncogenic drivers and the immune system in melanoma. J Clin Oncol 31: 499-506.

16. Celentano V, Luglio G, Antonelli G, Tarquini R, Bucci L (2011) Prophylactic surgery in Lynch syndrome. Tech Coloproctol 15: 129-134.

17. Lostumbo L, Carbine NE, Wallace J (2010) Prophylactic mastectomy for the prevention of breast cancer. Cochrane Database Syst Rev : CD002748.

18. Casciato, DA Cancer Chemotherapeutic agents. Page 53-124. In Manual of Clinical Oncology 7th Edition, 2012, editors Casciato DA, Territo MC. Wolters Kluwer.

19. Müller J, Nitschke L (2014) The role of CD22 and Siglec-G in B-cell tolerance and autoimmune disease. Nat Rev Rheumatol .
20. Wayne AS, Fitzgerald DJ, Kreitman RJ, Pastan I (2014) Immunotoxins for leukemia. Blood 123: 2470-2477.

21. Danel VC, Saviuc PF, Garon D (2001) Main features of Cortinarius spp. poisoning: a literature review. Toxicon 39: 1053-1060.

22. Pinter Brown LC, Casciato DA. Hodgkin and non-Hodgkin lymphoma. 508-552. In Manual of Clinical Oncology 7th Edition, 2012, editors Casciato DA, Territo MC. Wolters Kluwer.

23. Kudchadkar RR, Gonzalez R, Lewis K (2013) New targeted therapies in melanoma. Cancer Control 20: 282-288.

24. Territo MC. Hematopoietic stem cell transplantation. 856-865. In Manual of Clinical Oncology 7th Edition, 2012, editors Casciato DA, Territo MC. Wolters Kluwer.

25. Lord CJ, Ashworth A (2012) The DNA damage response and cancer therapy. Nature 481: 287-294. 